\title{
Geochronology of hydrocarbon accumulation in buried hills: evidence from fluid inclusion geochemistry \\ WEIKAI WEI XU
}

China University of Mining and Technology ( Beijing)

Presenting Author: 18810000743@163.com

The objective of geological evaluation of petroleum exploration is to accurately understand the formation and distribution of petroleum reservoirs, and the accumulation period is one of the core issues. The reservoir forming model of buried hill reservoir is complex, and there is a lack of systematic understanding of hydrocarbon charging time and accumulation period. The petroleum accumulation stages are determined by inclusion micro petrography, reservoir solid bitumen, hydrocarbon inclusion, fluid inclusion dating and authigenic illite $\mathrm{K}-\mathrm{Ar}$ isotopic age. Taking the typical Carboniferous-Permian inclusions in Huanghua depression as an example, the results show that there are two diagenetic minerals in the sandstone of Xiashihezi Formation of Permian in Wumaying buried hill, both of which are primary inclusions. Oil inclusions account for $25 \%$ \pm , oil-gas inclusions $65 \% \pm$, and natural gas inclusions $10 \% \pm$. The homogenization temperature is mainly a group, concentrated in $135 \sim 145^{\circ} \mathrm{C}$. The salinity of inclusions varies widely from 0 $\sim 22 \mathrm{Wt} \%$ to $3 \sim 18 \mathrm{Wt} \%$. Combined with burial history and paleogeothermal history, it is inferred that the petroleum inclusions in this period were formed at the end of Eocene, and the accumulation time started from $40 \mathrm{Ma} \pm$ and continues to this day. K-Ar isotope test of authigenic illite shows that the time of petroleum injection into the reservoir is $60 \mathrm{Ma} \pm$. The Carboniferous in Liugangzhuang buried hill has low oil production, with $25 \% \pm$ oil inclusions, $70 \% \pm$ petroleum inclusions and $5 \% \pm$ natural gas inclusions. The homogenization temperature of hydrocarbon-bearing brine inclusions is between $120^{\circ} \mathrm{C}$ and $130{ }^{\circ} \mathrm{C}$, and the salinity is between $3.87 \mathrm{Wt} \%$ and $6.88 \mathrm{Wt} \%$. According to the analysis of hydrocarbon accumulation period, there is a one-stage hydrocarbon accumulation process in the buried hill of the study area, and the accumulation time is different due to multi-stage structural superposition. It can be roughly divided into early Eocene, late Eocene and Miocene. Based on this, the petroleum accumulation period can be determined more accurately and quantitatively, which lays a theoretical foundation for petroleum source correlation and ancient petroleum reservoir exploration. 